\title{
Диспластична кардіопатія у футболістів: особливості прояву залежно від віку, статі та спортивного стажу
}

\author{
Н. В. Криволап
}

Донецький національний медичний університет ім. М. Горького, Донецьк, Україна

\begin{abstract}
Резюме. Представлен анализ различных вариантов дисплазии структур сердца, частота встречаемости малых аномалий сердца в зависимости от возраста, пола, тренировочного стажа лиц, занимающихся футболом. Проанализированы факторы, приводящие к снижению адаптационных возможностей у футболистов с проявленими дисплазии сердца.

Ключевые слова: диспластическая кардиопатия, спортсмены-футболисты, спортивный стаж, возможности осложнений.
\end{abstract}

Summary. The paper presents an analysis of the various options dysplasia cardiac structures, the incidence of heart anomalies depending on age, sex, length of training of persons involved in football. The factors leading to a decrease of adaptation are possibilities in football with the manifestation of dysplasia of the heart.

Key words: dysplastic cardiopathy, athletes, players, sport experience, the possibility of complications.

Постановка проблеми. Підвищені фрізичні та нервово-емоційні навантаження, які запропоновані сучасним рівнем тренувальної підготовки фрутболістів, розглядаються як фрактори ризику розвитку патологічних станів у гравців (Лисенчук, 2003). Таким чином, однією з найважливіших задач лікаря спортивної медицини $€$ моніторинг функціонального стану серцево-судинної системи фрутболістів. Очевидна необхідність ранньої діагностики початкових змін системи кровообігу, що передують розвиткові захворювання і етіопатогенетично пов'язані з ним [4]. Особливе значення при цьому надається диспластичній кардіопатії.

Незважаючи на досить велику кількість досліджень, проблема диспластичної кардіопатії незмінно викликає інтерес у багатьох дослідників, передусім через велику поширеність процесу в популяції [3].

За даними Т.С. Гуревич (2006) можна відзначити вірогідно більш високу поширеність проявів дисплазії з'єднувальної тканини у спортсменів ігрових видів спорту, пролапс мітрального клапана був діаностован у 57,1 \% баскетболістів.

Важливість проблеми диспластичних змін серця зв'язана з наявністю певних труднощів у правильній оцінці відхилень у функції серцевосудинної системи, обумовлених синдромом дисплазії структур серця [5].

Актуальність даного питання визначається ще й тим, що деякі особливості прояву диспластичної кардіопатії нерідко імітують неясні та важкодіагностуємі прояви ревматичного процесу, різні варіанти запальних уражень міокарда [8]. При цьому помилковий діагноз диктує традиційне обмеження тренувальних навантажень, що збільшує наявні порушення функції серцево-судинної системи, а також знижує адаптаційні можливості $[5,9]$.

Проведений аналіз літератури показує, що додаткові хорди серця і пролапс мітрального клапана $\epsilon$ анатомо-фрізіологічними френоменами, взаємозв'язок яких не визначено $[3,10]$. Прямих порівнянь параметрів фрункціонального стану міокарда у спортсменів із пролапсом мітрального клапана і додаткових хорд не проводилося.

Прогноз у фрутболістів із проявами диспластичної кардіопатії вивчений вкрай недостатньо. В цілому, він сприятливий при незначному ступені прояву пролапса мітрального клапана і сприятливому розташуванні додаткових хорд, однак маються суперечливі дані про підвищену частоту зустрічальності порушень ритму серця в обох групах $[3,6]$. Неясно, чи $\epsilon$ у клінічного симптомокомплексу цих фрутболістів відмінності від такого ж параметра спортсменів з вегетативними дисфрункціями, що не мають эхокардіографрічних феноменів диспластичної кардіопатії. Дані про вплив додаткових хорд серця і пролапса мітрального клапана на фрізичну працездатність також суперечливі.

Мета дослідження - підвищення ефективності медичного забезпечення тренувального 
процесу фрутболістів на основі виявлення поширеності і особливостей прогресування проявів диспластичної кардіопатії.

Методи та організація дослідження. Для вирішення поставлених завдань обстежено 301 фрутболіста віком від 13 до 36 років, з них - 237 спортсменів чоловіків і $64-$ жінок. Спортивний стаж - 3-27 років, спортивна кваліфікація від початківців, які не мають спортивного розряду, до спортсменів-професіоналів клубних команд (КМС, МС, МСМК, ЗМС). Дослідження проводилося в Обласному лікарсько-фрізкультурному диспансері Донецька під час проходження спортсменами поглибленого медичного огляду. Це - вивчення загального і спортивного анамнезу, об'єктивне обстеження, огляд 3 метою виявлення стигм дисплазії сполучної тканини. Проявом слабкості сполучної тканини може бути цілий комплекс фенотипічних ознак: підвищена еластичність шкіри, поздовжня плоскостопість, гіперрухливість у суглобах, астенічна статура (зниження масо-зростових показників), сколіози, недостатність венозних клапанів тощо. Оцінювали антропометричні дані: вимірювали масу тіла, зріст, а на їх основі проводили експрес-оцінку синдрому дисплазії сполучної тканини за допомогою індексу Варге:

$$
\begin{gathered}
\mathrm{IB}=\text { маса тіла (г) : зріст стоя- } \\
\text { чи (см) - вік (роки) : } 100 .
\end{gathered}
$$

При об'єктивному обстеженні всіх спортсменів було оглянуті з метою виявлення різних порушень статури. Для досліджень гіпермобільного синдрому застосовували стандартні критерії в модифрікації Р. Beighton, які оцінювали д'евятибальною оцінкою здатності спортсмена виконати п'ять рухів.

Проведено електрокардіографічне дослідження в стані спокою за загальноприйнятою методикою; ехокардіографрічне дослідження фрутболістів у М- і В-режимах з заміром основних кардіологічних параметрів; оцінку стану клапанного апарата серця; визначення адаптації фрутболістів з проявами диспластичної кардіопатії та без них до тренувальних і змагальних навантажень за допомогою тесту $\mathrm{PWC}_{170}$, реакції ЕКГпоказників на фрізичне навантаження.

Результати дослідження та їх обговорення. Різні прояви диспластичної кардіопатії (ДПК) виявлено у $42(17,7 \%)$ футболістів чоловічої статі, ці показники не відрізняється від аналогічних у популяції. Причому найбільшій відсоток різних варіантів диспластичних проявів був у групі три-шестирічного спортивного стажу, тобто у найменш тренованих фрутболістів, на початку селекційного відбору. Найменший відсоток проявів дисплазії серця - 8,9 \% - був у найбільш тренованих, професійних фрутболістів, які мали стаж тренувань більше 15 років. Взагалі відсоток різних проявів диспластичної кардіопатії у футболістів-чоловіків має чітку тенденцію до зниження при зростанні спортивного стажу.

Результати аналізу частоти виявлення кожного $з$ проявів диспластичної кардіопатії показують, що найчастіше серед фрутболістів-чоловіків зустрічаються пролапси мітрального клапана - в середньому у $12 \%$ випадків. Середня частота виявлення пролапса мітрального клапана в популяції складає 12-19. Серед обстежених футболістів цей діагноз встановлено у спортсменів 3 три-п'ятирічним стажем - у $16,6 \%$, а з 15-річним $-7,4 \%$, що вказує на тенденцію до зниження прояву диспластичної кардіопатії зі зростанням стажу тренувань. Причому зі збільшенням спортивного стажу зростає і відсоток пролабування стулок мітрального клапана, яке супроводжується систолічною регургітацією. Якщо в групі початківців (три-п'ять років) лише один із трьох випадків пролапса супроводжувався регургітацією, то надалі при збільшенні спортивного стажу кількість пролапсів з наявністю систолічної регургітації значно перебільшує кількість їх без регургитації; у групі фрутболістів зі стажем тренувань понад 15 років мали місце лише пролапси мітрального клапана з наявністю систолічної регургітації - п'ять $(7,4$ \%) випадків. Пролапс трикуспідального клапана було діагностовано в одному випадку $(1,4 \%)$ у фрутболіста зі спортивним стажем д'евять років у поєднанні з пролапсом мітрального клапана та наявністю аномально розташованої (APX) в порожнині лівого шлуночка хорди.

Доволі часто виявляються також аномально розташовані хорди в порожнині лівого шлуночка. У фрутболістів зі стажем тренувань три-п'ять та шість-вісім років APX зустрічаються в однаковому відсотку випадків - 16,6 \%, причому частіше було виявлено хорди, розташовані в середній третині лівого шлуночка. Зі зростанням спортивного стажу тренованості відсоток виявлення АРX зменшується до 5,9 \% в групі фрутболістів зі стажем тренувань більше 15 років. У обстежених фрутболістів також були виявлені більш рідкісні варіанти диспластичної кардіопатії: двостулковий аортальний клапан (в 5,5\% випадків серед початківців (стаж тренувань три-п'ять років) і в $2,3 \%$ випадків - в групі зі спортивним стажем шість-вісім років) та десрект міжпередсердної перетинки (відкрите овальне вікно) в аналогічному відсотку випадків і в тих же групах (три-п'ять 
та шість-вісім років спортивного стажу 5,5 та 2,3 \% відповідно).

Різні прояви диспластичної кардіопатії (ДКП) виявлено у жінок 14 (21,8 \%), які займаються фрутболом - на 4 \% більше, ніж у чоловіків. Серед жінок-фрутболісток найбільший відсоток проявів диспластичної кардіопатії - 28,2 \% припадає на групу менш тренованих футболісток зі стажем три-п'ять років. Причому на відміну від чоловіків, у жінок частіше зустрічалися аномально розташовані хорди та вони частіше були множинні. Далі за частотою виявлення знаходяться пролапси мітрального клапана, вони діагностовані у п'яти (7,8%) фрутболісток, які мали стаж тренувань 3-12 років, у жінок ПМК частіше були ізольованими. Двостулковий аортальний клапан зафіксовано у однієї спортсменки, яка мала спортивний стаж шість років. Дефект міжпередсердної перетинки був теж у однієї жінки зі стажем тренувань три роки. Найменший 8,3 \% - відсоток виявлених варіантів ДКП був зареєстрований (як і у чоловіків) у найбільш тренованих спортсменок зі стажем більше 12 років.

Найчастіше, в 15 випадках $(35,7 \%)$, різні прояви диспластичної кардіопатії у футболістів чоловічої статі не супроводжується френотипічними ознаками недиференційованої дисплазії сполучної тканини. Серед інших стигм изембріогенезу частіше в поєднанні з диспластичною кардіопатією зустрічаються синдром гіперрухливості суглобів та порушення постави у дев'яти $(21,4$ \%) випадках. У семи випадках ДКП супроводжувалися астенічною будовою тіла, що складає $16,6 \%$ і лише у двох (4,7\%) випадках наявність у спортсменів диспластичної кардіопатії супроводжувалась ознаками з боку органів зору. Взагалі, найбільший - 45,4 \% - відсоток відсутності фенотипічних проявів дисплазії був зафріксований при аномально розташованих хордах в порожнині лівого шлуночка. В однаковому відсотку випадків $(38,4 \%)$ відсутність френотипічних ознак виявлено як при наявності ізольованого пролапса мітрального клапана, так і при поєднанні його з АРХ. Тільки при поєднанні найбільш рідкісних проявів ДКП у футболістів-чоловіків діагностовано практично всі варіанти фенотипічних ознак дисплазії сполучної тканини. У фрутболісток диспластична кардіопатія проявляється частіше або супроводжуються ознаками дисплазії з боку органів зору, чи не має френотипічних ознак.

Найрідше у жінок зустрічається астенічна будова тіла - всього в одному (7,1 \%) випадку. Поєднані варіанти ДКП у спортсменок, які займаються фрутболом, завжди були з фенотипічними ознаками дисплазії сполучної тканини, частіше - 3 гіпермобільним синдромом (у двох випадках) та астигматизмом (в одному випадку). А порушення постави було діагностовано лише у фрутболісток, які мали ізольований пролапс мітрального клапана. Взагалі і серед чоловіків, і серед жінок такий варіант ДКП, як наявність аномально розташованих хорд, більш, ніж інші супроводжується різними фенотипічними ознаками недеференційованої дисплазії (45,4 та 50\% відповідно).

Різноманітні прояви диспластичної кардіопатії були діагностовані у 42 фрутболістів-чоловіків та 14 жінок і було віднесено до основних груп спостереження, до контрольних увійшли футболісти, у яких не було проявів диспластичної кардіопатії, - 44 та 16 осіб відповідно (табл. 1).

Загалом достовірних розбіжностей в структурних характеристиках серця у фрутболістів основної і контрольної груп немає: і маса міокарду, і кінцево-діастолічний об'єм лівого шлуночка поступово підвищуються зі зростанням спортивного стажу. Разом з цим у фрутболістів основної групи, на відміну від контрольної, і маса міокарда (MM), і індекс маси міокарда (IMM) продовжують достовірно збільшуватися з ростом спортивної майстерності (стаж понад 13 років).

У фрутболістів контрольної групи з ростом спортивного стажу достовірно вищі показники кінцево-діастолічного (КДО) і кінцево-систолічного об'єму (КСО), що свідчить про більш гармонічний варіант адаптації до тренувальних навантажень спортсменів, у яких немає проявів диспластичної кардіопатії. Достовірно нижчі показники фрракції викиду у фрутболістів контрольної групи ( $<0,05)$ вказують на так званий повний або неповний синдром регульованої гіподинамії міокарда, що говорить про прояв принципу економічності серцевої діяльності у спортсменів в умовах спокою. У спортсменів-чоловіків основної групи після 12 років систематичних занять фуутблом виявлено достовірне збільшення фрракції викиду, що вказує на дезадаптацію. Можна побачити достовірну різницю між показниками маси міокарда та індексу маси міокарда у фрутболісток основної та контрольної груп, причому ці показники вищі у жінок основної групи. Але якщо розглядати зміни структурних показників в групах, то було відмічено достовірне збільшення ММ, ІММ, КДО, КСО і ЛП (розмір лівого передсердя) у спортсменок контрольної групи з ростом спортивного стажу, що свідчить про гармонійну адаптацію спортивного серця зі збільшенням фрізичних навантажень. В основній 
ТАБЛИЦЯ 1 - Частота співвідношення фенотипічних ознак недиференційованої дисплазії сполучної тканини з різними проявами диспластичної кардіопатії серед футболістів

\begin{tabular}{|c|c|c|c|c|c|c|c|c|c|c|}
\hline \multirow{3}{*}{$\begin{array}{c}\text { Фенотипічні ознаки } \\
\text { ДСТ }\end{array}$} & \multicolumn{8}{|c|}{ Прояви диспластичної кардіопатії } & \multirow{2}{*}{\multicolumn{2}{|c|}{$\begin{array}{c}\text { Всього } \\
\text { обстежених }\end{array}$}} \\
\hline & \multicolumn{2}{|l|}{ пмк } & \multicolumn{2}{|l|}{ APX } & \multicolumn{2}{|c|}{ ПМК+АРX } & \multicolumn{2}{|c|}{ інші прояви ДКП } & & \\
\hline & $\begin{array}{c}\text { Абсолютна } \\
\text { кількість }\end{array}$ & $\%$ & $\begin{array}{l}\text { Абсолютна } \\
\text { кількість }\end{array}$ & $\%$ & $\begin{array}{l}\text { Абсолютна } \\
\text { кількість }\end{array}$ & $\%$ & $\begin{array}{l}\text { Абсолютна } \\
\text { кількість }\end{array}$ & $\%$ & $\begin{array}{l}\text { Абсолютна } \\
\text { кількість }\end{array}$ & $\%$ \\
\hline \multicolumn{11}{|c|}{ Чоловіки } \\
\hline $\begin{array}{l}\text { Астенічна } \\
\text { статура }\end{array}$ & 3 & 23,8 & 1 & 9 & 2 & 15,3 & 1 & 20 & 7 & 16,6 \\
\hline $\begin{array}{l}\text { Гіпермобільний } \\
\text { синдром }\end{array}$ & 2 & 15,3 & 3 & 27,2 & 2 & 15,3 & 2 & 40 & 9 & 21,4 \\
\hline $\begin{array}{l}\text { Порушення } \\
\text { постави }\end{array}$ & 3 & 23,8 & 2 & 18,1 & 3 & 23,8 & 1 & 20 & 9 & 21,4 \\
\hline $\begin{array}{l}\text { Міопія або } \\
\text { астигматизм }\end{array}$ & - & - & - & - & 1 & 7,6 & 1 & 20 & 2 & 4,7 \\
\hline Без фенотипічних ознак & 5 & 38,4 & 5 & 45,4 & 5 & 38,4 & - & - & 15 & 35,7 \\
\hline Кількість обстежених (n) & \multicolumn{2}{|l|}{13} & \multicolumn{2}{|l|}{11} & \multicolumn{2}{|l|}{13} & \multicolumn{2}{|l|}{5} & \multicolumn{2}{|l|}{42} \\
\hline \multicolumn{11}{|c|}{ Жінки } \\
\hline $\begin{array}{l}\text { Астенічна } \\
\text { статура }\end{array}$ & 1 & 20 & - & - & - & - & - & - & 1 & 7,1 \\
\hline $\begin{array}{l}\text { Гіпермобільний } \\
\text { синдром }\end{array}$ & - & - & 1 & 16,6 & 1 & 100 & 1 & 50 & 3 & 21,4 \\
\hline $\begin{array}{l}\text { Порушення } \\
\text { постави }\end{array}$ & 2 & 40 & - & - & - & - & - & - & 2 & 14,2 \\
\hline $\begin{array}{l}\text { Міопія або } \\
\text { астигматизм }\end{array}$ & 1 & 20 & 2 & 33,3 & - & - & 1 & 50 & 4 & 28,4 \\
\hline $\begin{array}{l}\text { Без френотипічних } \\
\text { ознак }\end{array}$ & 1 & 20 & 3 & 50 & - & - & - & - & 4 & 28,4 \\
\hline Кількість обстежених (n) & \multicolumn{2}{|l|}{5} & \multicolumn{2}{|l|}{6} & \multicolumn{2}{|l|}{1} & \multicolumn{2}{|l|}{2} & \multicolumn{2}{|l|}{14} \\
\hline
\end{tabular}

ТАБЛИЦЯ 2 - Співвідношення основних структурно-функціональних показників серця у футболістів залежно від спортивного стажу (3-13 років)

\begin{tabular}{|c|c|c|c|c|c|}
\hline \multirow{2}{*}{ Показник } & \multicolumn{3}{|c|}{ Чоловіки } & \multicolumn{2}{|c|}{ Жінки } \\
\hline & 3-7 років & 8-12 років & $>13$ років & 3-7 років & $>8$ років \\
\hline \multicolumn{6}{|c|}{ Основна група } \\
\hline Кількість обстежених & 7 & 19 & 16 & 8 & 6 \\
\hline MM, г & $172,8 \pm 8$ & $195,5 \pm 3,8^{*}$ & $202,3 \pm 6,7^{*}$ & $125,2 \pm 10,7$ & $136,9 \pm 4,9$ \\
\hline $\mathrm{IMM}, \Gamma \cdot \mathrm{M}^{-2}$ & $96,5 \pm 3,1$ & $103,4 \pm 1,3^{*}$ & $103,2 \pm 5,1$ & $78,6 \pm 5,9$ & $84,3 \pm 2,8$ \\
\hline лП, мм & $34,3 \pm 9,5$ & $36,7 \pm 0,7$ & $37,6 \pm 0,6$ & $31,8 \pm 1,4$ & $34 \pm 1$ \\
\hline КДО, мл & $138,9 \pm 8,2$ & $157,6 \pm 50,6^{*}$ & $182,7 \pm 3,4^{*}$ & $103,3 \pm 7$ & $110,1 \pm 3,6$ \\
\hline КСО, мл & $38,8 \pm 3$ & $43,2 \pm 3,7$ & $45,3 \pm 1,9$ & $23,1 \pm 0,9$ & $26,1 \pm 1,2$ \\
\hline$\Phi \mathrm{B}, \%$ & $71,2 \pm 1,4$ & $73,2 \pm 1,3$ & $75,4 \pm 6=0,7 *$ & $74,6 \pm 1$ & $71,8 \pm 1$ \\
\hline \multicolumn{6}{|c|}{ Контрольна група } \\
\hline Кількість обстежених & 9 & 19 & 16 & 9 & $>7$ \\
\hline MM, г & $190,5 \pm 4,8$ & $202,3 \pm 3,3^{*}$ & $203 \pm 6,3$ & $113,9 \pm 2,5$ & $131,3 \pm 2,4^{*}$ \\
\hline $\mathrm{IMM}, \Gamma \cdot \mathrm{M}^{-2}$ & $104,2 \pm 3$ & $104,5 \pm 1,5$ & $107,3 \pm 0,6$ & $70,3 \pm 1,4$ & $79,9 \pm 1,1^{*}$ \\
\hline ЛП, мм & $35,5 \pm 0,8$ & $37,8 \pm 0,4^{*}$ & $39,2 \pm 0,4^{*}$ & $29,7 \pm 0,75$ & $32,3 \pm 0,75^{*}$ \\
\hline КДО, мл & $144,5 \pm 9,3$ & $170,4 \pm 5^{*}$ & $186,4 \pm 3,7^{*}$ & $94,8 \pm 3,1$ & $108,7 \pm 3,4^{*}$ \\
\hline КСО, мл & $43,2 \pm 2,7$ & $44,9 \pm 2$ & $51,3 \pm 2,2^{*}$ & $22,3 \pm 1,1$ & $26,2 \pm 1,2^{*}$ \\
\hline ФВ, \% & $70 \pm 1$ & $73,3 \pm 0,8$ & $71,4 \pm 0,8$ & $72,3 \pm 0,6$ & $72,7 \pm 0,8$ \\
\hline
\end{tabular}

Примітка: результати представлено в форматі: «Медіана (інтерквартильний розмах)».

*Наявність статистично значущої відмінності за критерієм Манна-Уітні $(p<0,05)$ 
групі достовірних відмінностей в залежності від стажу не було виявлено. На відміну від чоловіків, у жінок в основній і контрольній групах показники фрракції викиду (ВФ) не змінювались залежно від спортивного стажу (табл. 2).

Взагалі виявлено достовірні розбіжності в показниках фрізичної працездатності та відношення цього показника до маси міокарда у чоловіків основної і контрольної груп: у футболістів контрольної групи показники $\mathrm{PWC}_{170}$ та $\mathrm{PWC}_{170} /$ MM достовірно більші, ніж в основній. Можна побачити чітку залежність: величини показників $\mathrm{PWC}_{170}\left(\right.$ кгм $\left.\cdot \mathrm{xB}^{-1}\right), \mathrm{PWC}_{170}\left(\right.$ кгм $\left.\cdot \mathrm{xB}^{-1} \cdot \mathrm{K}^{-1}\right)$, PWC $_{170} /$ КДО та РWC $_{170} / \mathrm{MM}$ у фрутболістів основної групи достовірно зменшуються після восьми років спортивного стажу. Тобто саме в цей період (8-12 років стажу), незважаючи на систематичний характер тренувань та адаптаційні зміни структурно-функціональних параметрів серця (збільшення ММ та КДО) функціональні можливості фрутболістів з проявами диспластичної кардіопатії достовірно знизились. А починаючи з 13 років занять фрутболом адаптаційні зміни структури серця дозволяють спортсменам збільшувати фрункціональні можливості організму, і внаслідок цього показники фрізичної працездатності починають зростати. Це збігається з початком сенситивного періоду у підготовці спортсменів. У фрутболістів без проявів дисплазії серця незважаючи на поступове збільшення ММ та КДО, зі зростанням спортивного стажу показники фрізичної працездатності постійно знаходились в межах величин, вищих за середні (табл. 3).

Серед фрутболісток не виявлено достовірної різниці між структурними показниками серця та їх співвідношенням 3 величинами фрізичної працездатності в залежності від спортивного стажу. Всі показники, які характеризують адаптаційні можливості організму спортсменок, мали тенденцію до збільшення пропорційно-спортивному стажу. Це ствердження потребує подальшого вивчення.

Загалом серед фрутболістів-чоловіків основної групи різні патологічні зміни ЕКГ-показників у стані спокою зустрічаються в 50 \% випадків. Найчастіше вони представлені порушеннями процесів реполяризації - у 12 осіб (28,5 \%) з різним спортивним стажем, причому у більшості 3 них - у 9 осіб (75 \%) - це порушення процесів реполяризаціїі задньої стінки лівого шлуночка (ППРЗСЛШ) або (25 \%) - дифрузні зміни реполяризації. У фрутболістів-чоловіків контрольної групи зареєстровано тільки порушення процесів реполяризаціїї задньої стінки лівого шлуночка у 8 осіб (18\%), що значно менше, ніж в основній групі. Однак частіше ППРЗСЛШ виявлялись у фрутболістів основної і контрольної груп, які мали спортивний стаж 8-12 років - по п'ять (26,3%) випадків. У футболістів обох груп зі стажем більше 13 років ППРЗСЛШ також було зафіксовано

ТАБЛИЦЯ 3 - Залежність показників фізичної працездатності та співвідношення PWC $_{170}$ зі структурними показниками серця футболістів від спортивного стажу (3-13 років)

\begin{tabular}{|c|c|c|c|c|c|}
\hline \multirow{2}{*}{ Показник } & \multicolumn{3}{|c|}{ Чоловіки } & \multicolumn{2}{|r|}{ Жінки } \\
\hline & 3-7 років & 8-12 років & $>13$ років & 3-7 років & $>8$ років \\
\hline \multicolumn{6}{|c|}{ Основна група } \\
\hline Кількість обстежених & 7 & 19 & 16 & 8 & 6 \\
\hline $\begin{array}{l}\text { PWC170 } \\
\text { КГM } \cdot \mathrm{XB}^{-1} \\
\mathrm{~K} \Gamma \mathrm{M} \cdot \mathrm{XB}^{-1} \cdot \mathrm{K}^{-1}\end{array}$ & $\begin{array}{c}1861,9 \pm 109,1 \\
27,1 \pm 1,5\end{array}$ & $\begin{array}{c}1554,0 \pm 49,1^{*} \\
21,3 \pm 0,6^{*}\end{array}$ & $\begin{array}{c}1730,3 \pm 70,1^{*} \\
23,3 \pm 0,75^{*}\end{array}$ & $\begin{array}{c}1368,6 \pm 77,0 \\
24,9 \pm 2\end{array}$ & $1492,3 \pm 117,424,15 \pm 1,5$ \\
\hline $\mathrm{PWC}_{170} /$ КДО & $13,5 \pm 2,4$ & $10,0 \pm 1,8^{*}$ & $9,4 \pm 1,5$ & $13,3 \pm 0,4$ & $13,4 \pm 0,8$ \\
\hline $\mathrm{PWC}_{170} / \mathrm{MM}$ & $10,9 \pm 0,9$ & $8,0 \pm 0,25^{\star}$ & $8,1 \pm 0,3$ & $11,2 \pm 0,6$ & $10,8 \pm 0,6$ \\
\hline \multicolumn{6}{|c|}{ Контрольна група } \\
\hline Кількість обстежених & 9 & 19 & 16 & 9 & 7 \\
\hline $\begin{array}{l}\text { PWC170 } \\
\text { КгM } \cdot \mathrm{XB}^{-1} \\
\mathrm{~K} \Gamma \mathrm{M} \cdot \mathrm{XB}^{-1} \cdot \mathrm{K}^{-1}\end{array}$ & $\begin{array}{c}1821,4 \pm 139,6 \\
25,6 \pm 2,6\end{array}$ & $\begin{array}{c}1849,2 \pm 70,7 \\
24,7 \pm 1,1\end{array}$ & $\begin{array}{c}1874,9 \pm 39 \\
24,8 \pm 0,8\end{array}$ & $\begin{array}{c}1451,3 \pm 85,9 \\
23,8 \pm 1,4\end{array}$ & $\begin{array}{l}1550,1 \pm 86 \\
24,8 \pm 1,25\end{array}$ \\
\hline $\mathrm{PWC}_{170} /$ КДО & $12,8 \pm 3,3$ & $11,0 \pm 2,2$ & $10,1 \pm 1,25$ & $15,3 \pm 0,9$ & $14,3 \pm 0,8$ \\
\hline $\mathrm{PWC}_{170} / \mathrm{MM}$ & $9,5 \pm 0,7$ & $9,1 \pm 0,3$ & $8,95 \pm 0,2$ & $12,7 \pm 0,6$ & $11,7 \pm 0,5$ \\
\hline
\end{tabular}

Примітки. Результати представлено в форматі: «Медіана (інтерквартильний розмах)».

*Наявність статистично значущої відмінності за критерієм Манна-Уітні $(p<0,05)$. 
в однаковому відсотку випадків - по 18,7 \%. Але деякі зміни були тільки у футболістів основної групи: фрібриляція передсердь та синдром WPW - по одному випадку $(14,2 \%)$ у найменш тренованих ффутболістів, зі спортивним стажем 3-7 років.

Неадекватну реакцію ЕКГ-показників на фрізичне навантаження проби $\mathrm{PWC}_{170}$ у вигляді порушення ритму зареєстровано у фрутболістівчоловіків основної групи. У двох спортсменів зі спортивним стажем 8-12 (10,5 \%) та двох зі стажем більше 12 років (12,5 \%) виявлено надшлуночкову та шлуночкову екстрасистолію при проведенні фрункціональної проби. Це $є$ порушенням адаптації до фрізичних навантажень у фрутболістів з проявами диспластичної кардіопатії.

У жінок-футболісток патологічні зміни ЕКГ-показників спостерігались у вигляді порушення процесів реполяризації по задній стінці лівого шлуночка тільки в основній групі: у двох осіб (25\%) зі спортивним стажем 3-7 років та у двох $(33,3 \%)$ - зі стажем більше 8 років. Після велоергометрії реакція ЕКГ-показників у всіх фрутболісток була адекватною.

\section{Висновки}

1. Встановлено, що частота виявлення синдрому гіпермобільності суглобів знижується 3 віком як у жінок, так і у чоловіків, порушення постави у фрутболістів-чоловіків всіх вікових груп зустрічаються приблизно в однаковому відсотку випадків, але в меншому відсотку, ніж у представників інших видів спорту. На відміну від чоловіків, у жінок-футболісток порушення постави частіше зустрічаються в більш молодому віці.

2. Прояви диспластичної кардіопатії виявлено у $17,7 \%$ футболістів та $21,8 \%$ фрутболісток, причому ці показники практично не відрізняються від аналогічних в популяції. Взагалі відсоток виявлення різних проявів диспластичної кардіопатії

\section{Література}

1. АбрамоВ С. В. Оцінка функціонального стану серцево-судинної системи юних спортсменок, що займаються циклічними видами спорту / С. В. Абрамов, А. С. Почепня, А. І. Послайко // Мед. перспективи. - 2001. - N 1. C. $110-114$.

2. Апанасенко Г. Л. Профилактика в кардиологии: необходимость новой стратегии / Г. Л. Апанасенко // Здоров'я України. - 2004. - № 22 (107). - С. 8-9.

3. Земцовский Э. В. Спортивная кардиология / Э. В. Земцовский. - СПб. : Гиппократ, 1995. - 448 с.

4. Макарова Г. А. Спортивная медицина: учебник / Г. А. Макарова. - М. : Сов. спорт, 2004. - 480 с.

5. Сердие в условиях спортивной деятельности: физиологические и врачебно-педагогические аспекты: пособие у фрутболістів має чітку тенденцію до зниження при зростанні спортивного стажу. Найменший відсоток зареєстрований і серед жінок, і серед чоловіків у найбільш тренованих спортсменів зі спортивним стажем більше 12 років.

3. Достовірних розбіжностей в структурних характеристиках серця у фрутболістів-чоловіків основної і контрольної груп виявлено не було: і маса міокарда, і кінцево-діастолічний об'єм лівого шлуночка поступово збільшуються з ростом стажу тренувань, але уповільнюється адаптаційна перебудова серця до фрізичних навантажень у футболістів основної групи після 12 років спортивного стажу; у фрутболістів чоловічої та жіночої статі контрольної групи з ростом стажу після 8 років тренувань достовірно збільшуються показники і КДО і КСО.

4. Величини показників фрізичної працездатності та відношення цього показника до структурно-функціональних показників серця $\mathrm{PWC}_{170}$

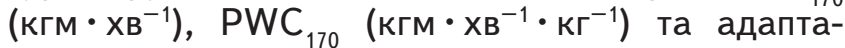
ційних коефіцієнтів: $\mathrm{PWC}_{170} /$ КДО та $\mathrm{PWC}_{170} /$ MM у фуутболістів 3 проявами диспластичної кардіопатії достовірно зменшуються після 8 років, вони виявились достовірно нижчими, ніж у фрутболістів контрольної групи. Серед фрутболісток основної та контрольної груп не виявлено достовірної різниці між структурними показниками серця та їх співвідношенням з величинами фрізичної працездатності в залежності від спортивного стажу.

5. Порушення реакції функціональних показників на фрізичне навантаження частіше з'являються після 8 років тренувань у футболістів-чоловіків в обох групах спостереження. У жінок залежності цього показника від стажу тренувань не виявлено. Неадекватна реакція на фізичне навантаження проби PWC $_{170}$ у вигляді порушення ритму була зареєстрована лише у фрутболістів-чоловіків основної групи.

\section{References}

1. Abramov S. V. Evaluation the functional state of the cardiovascular system for young athletes involved in cyclic sports / S. V. Abramov, A. S. Pochepnya, A. I. Poslaiko // Medychni perspektyvy. - 2001. - N1. - P. 110114.

2. Apanasenko G. L. The Prevention in Cardiology: the need for a new strategy/G. L. Apanasenko // The Health of Ukraine. - 2004. - N 22(107). - P. 8-9.

3. Zemtsovsky E. V. Sports Cardiology / E. V. Zemtsovsky. - St. Petersburg: Hippocrat, 1995. - 448 p.

4. Makarova G. A. Sports medicine / G. A. Makarova. Moscow: Sovetskiy Sport, 2004. - 480 p.

5. Heart in conditions of sports activity: physiological, medical and pedagogical aspects / V. Y. Yako- 
для фризиологов и врачей, работающих в области фризической культуры и спорта / [В. Я. Якобашвили, Г. А. Макарова, М. Л. Игельник, В. В. Бессчастная]. - М.: Сов. спорт, 2006. -234 c.

6. Структурные и функциональные особенности сердца у профессиональных фрутболистов после прекращения многолетней спортивной деятельности / О. В. Козырева, Е. В. Богданова, З. Б. Белоцерковский [и др.] // Физиология человека. - 2007. - Т. 33, N 4. - С. 119-125.

7. Халафяян A. A. STATISTICA 6. Статистический анализ данных / А. А. Халафрян. - М.: ООО «Бином-Пресс», 2007. -512 c

8. Considerations for the interpretation of epidemiological studies of injuries in team sports: illustrative examples / [L. E. Hammond, J. M. Lilley, G. D. Pope et al.] // Clin. J. Sport Med. - 2011. - Vol. 21, N 2. - P. 77-79.

9. Maron B. J. The heart of trained athletes: cardiac remodeling and the risks of sports, including sudden death / B. J. Maron, A.Pelliccia // Circulation. - 2006. - Vol. 114, №15. - P. 1633-1644.

10. Trends in sudden cardiovascular death in young competitive athletes after implementation of a preparticipation screening program / Corrado D., Basso C., Pavei A. [et al.] // JAMA. - 2006. - Vol. 296, № 13. - P. 1593-601. bashvili, G. A. Makarova, M. L. Igelnik, V. V. Beschasnaya. - Moscow (Russia): Sovetskiy Sport, 2006. 234 p.

6. Structural and functional features of heart for professional football players after the cessation of long-term sports activities / O. V. Kozireva, E. V. Bogdanova, Z. B. Belotserkovsky, B. G. Lubina, A. V. Smolensky, V. V. Sagitova // The human physiology. - 2007. - N 33(4). - P. 119-125.

7. Halafyan A. A. STATISTICA 6 . The statistical analysis of the data / A. A. Halafyan. - Moscow: Open Company «Binpress», 2007. - $512 \mathrm{p}$.

8. Considerations for the interpretation of epidemiological studies of injuries in team sports: illustrative examples / [L. E. Hammond, J. M. Lilley, G. D. Pope et al.] // Clin. J. Sport Med. - 2011. - Vol. 21, N 2. - P. 77-79.

9. Maron B. J. The heart of trained athletes: cardiac remodeling and the risks of sports, including sudden death / B. J. Maron, A.Pelliccia // Circulation. - 2006. - Vol. 114, №15. - P. 1633-1644.

10. Trends in sudden cardiovascular death in young competitive athletes after implementation of a preparticipation screening program / Corrado D., Basso C., Pavei A. [et al.] // JAMA. - 2006. - Vol. 296, N 13. P. 1593-601. 